\title{
Основні етапи розвитку футурології та їі завдання в умовах сучасного світу
}

\author{
Сухорольський П. М., Сухорольська І. Ю., Національний університет «Львівська політехніка»
}

Стаття присвячена короткому огляду історії футурології, без якого практично неможливо зрозуміти завдання і особливості цієї міждисциплінарної галузі знань. 3 цією метою розкрито та охарактеризовано ключові ідеї, концепції і події на шляху розвитку футурології як окремої наукової дисципліни, виділено основних мислителів і вчених, яких можна вважати видатними футурологами свого часу. Всю історію становлення футурології розділено на чотири етапи, зокрема: витоки, зародження дисципліни, виникнення основних концепцій та інституцій, систематизація знань у відповідь на нові виклики глобалізованого світу. 3-поміж витоків футурології виділено релігію, утопію, наукову фантастику, історицизм, а також досягнення соціальних наук у міжвоєнний період. Зародження футурології пов'язане з утворенням центрів дослідження і обговорення майбутніх перспектив людства у США та Європі на початковому етапі холодної війни. До найважливіших подій наступної стадії розвитку футурології зараховано заснування Всесвітньої федерації футурології та впровадження перших футуроорієнтованих університетських курсів і освітніх програм. Стосовно останньої стадії акцентовано увагу на проблемах технологічного домінування, дегуманізації та глобалізації, які можна вважати головними викликами для людства у теперішній час та актуальними темами для футурологічних досліджень. У висновках визначено основні завдання сучасної футурології, що пов'язані з критичною оцінкою реальності, виявленням тенденцій, а також створенням образів бажаного майбутнього.

Ключові слова: майбутнє; утопія; прогнозування; постіндустріалізм; глобалізація; технологізація; образ майбутнього

\section{Futures studies: main stages of development and tasks in the modern world}

\author{
Sukhorolskyi P. M., Sukhorolska I. Yu., Lviv Polytechnic National University
}

Futures studies is an evolving discipline that becomes more and more needed in today's globalized world. The paper is devoted to the brief overview of the futures studies' history without which it is hardly possible to understand the tasks and peculiarities of this interdisciplinary field of knowledge. For this purpose, the key ideas, concepts, and events on the way of development of futures studies as a separate discipline are revealed and characterized; the thinkers and scholars considered to be outstanding futurists of the past and present are also mentioned. The whole history of futures studies is divided into four stages, including the origins, the emergence of the discipline, the creation of basic concepts and institutions, and the systematization of knowledge in response to the new challenges of the globalized world.

The origins of futures studies are related to religion, utopia, science fiction, historicism, and social sciences achievements in the interwar period. The emergence of futures studies is associated with the establishment of centres for research and discussion of future prospects of mankind in the United States and Europe in the early Cold War period. The setting up of the World Futures Studies Federation and the introduction of the first futures-oriented university courses and educational programs are considered the most important events of the following stage of futures studies development. This period is also associated with the emergence of the concepts of post-industrial society, global problems, sustainable development, which became crucial for futures studies and international policy design in the next decades. With regard to the present stage, the emphasis is laid on the emergence of fundamental theoretical works in the field of futures studies, the development of new methods and techniques of futures research, and the launch of government and corporate foresight projects. It is concluded that the problems of technological dominance, dehumanization, globalization appear to be the main challenges for mankind in the present world and the most topical themes for research. In the end, the main tasks of modern futures studies concerning critical assessment of reality, identification of trends for exploiting opportunities and counteracting threats, and creation preferable images of the future are defined.

Keywords: future; utopia; forecasting; post-industrialism; globalization; technologization; image of the future

\section{Основные этапы развития футурологии и ее задачи в условиях современного мира}

\section{Сухорольский П. М., Сухорольская И. Ю., Национальный университет «Львовская политехника»}

Статья посвящена краткому обзору истории футурологии, без которого практически невозможно понять задачи и особенности этой междисциплинарной области знания. С этой целью раскрыты и охарактеризованы ключевые идеи, концепции и события на пути развития футурологии как отдельной научной дисциплины, выделены основные мыслители и ученые, которых можно считать выдающимися футурологами своего времени. Вся история футурологии разделена на четыре этапа, включая истоки, зарождение дисциплины, возникновение основных 
концепций и институций, систематизацию знаний в ответ на новые вызовы глобализированного мира. Истоки футурологии имеют отношение к религии, утопии, научной фантастике, историцизму, а также достижениям социальных наук в межвоенный период. Зарождение футурологии связывается с образованием центров исследования и обсуждения будущих перспектив в США и Европе в ранний период холодной войны. К важнейшим событиям следующей стадии развития футурологии отнесены основание Всемирной федерации футурологии и внедрение первых футуро-ориентированных университетских курсов и образовательных программ. Что касается нынешней стадии, акцентировано внимание на проблемах технологического доминирования, дегуманизации и глобализации, которые можно считать главными вызовами для человечества и актуальными темами для футурологических исследований в настоящем мире. В выводах определены основные задачи современной футурологии, связанные с критической оценкой реальности, выявлением тенденций, а также созданием образов желаемого будущего.

Ключевые слова: будущее; утопия; прогнозирование; постиндустриализм; глобализация; технологизация; образ будущего

\section{Постановка проблеми.}

$\mathrm{B}$ продовж останніх десятиліть слово футурологія стало звичним для багатьох людей і не викликає жодного здивування у найрізноманітніших контекстах. Однак, необхідно усвідомлювати, що поряд із побутовим розумінням «футурології» як широкої сфери передбачень і фантазій на тему майбутнього $є$ і вужчі іiї інтерпретації як окремої наукової дисципліни (чи міждисциплінарної сфери знань), для якої вже розроблені і погоджені в межах наукового співтовариства власні теоретичні засади, принципи, методи пізнання та основні напрямки наукового пошуку. Така дисципліна вже тривалий час розвивається на Заході, а також в інших провідних наукових центрах у всьому світі та відома в англомовній науці під назвою futures studies. Саме іiі ми позначаємо українським терміном «футурологія» у даній статті. Напрацювання цієї дисципліни $є$ недостатньо висвітленими в українській науці, для якої футурологія нерідко означає: 1) виключно наукове прогнозування майбутнього (незважаючи на його досить обмежений потенціал через надзвичайну складність суспільних процесів, залежність суспільного розвитку від дій, які вчиняються у теперішньому, та багатьох інших чинників; неможливість спрогнозувати з високою імовірністю глобальні ключові для розвитку світу події неодноразово вже доводила історія, тому не дивно, що глобальне прогнозування нерідко набуває вигляду «глобального гадання» або взагалі відривається від реальності, не помічаючи через вузький науковий погляд чи вузьку практичну спрямованість очевидних речей), або ж іншу крайність - 2) сферу фантазій і домислів про майбутнє без жодних рамок і обмежень, що, очевидно, суттєво зменшує цінність таких «футурологічних» напрацювань. У зв'язку з цим досягнення futures studies, які базуються, з одного боку, на актуальних на сьогодні інтерпретаціях сутності і завдань соціально-гуманітарної науки, а 3 іншого - на усвідомленні ролі творчості та інтуїції у процесі наукової діяльності, потрібно включити до українського суспільствознавчого дискурсу. Насамперед, для формування загального уявлення про те, чим є сучасна футурологія, важливо зробити огляд історії iii становлення.

\section{Аналіз досліджень і публікацій.}

Теоретичною основою статті стали роботи провідних футурологів сучасності Венделла Белла (Wendell Bell), Річарда Слотера (Richard Slaughter), Джеймса Дейтора (James Dator), Coхаіла Інаятулли (Sohail Inayatullah) та інших. Безпосередньо питання становлення футурології як наукової дисципліни висвітлені у працях В. Белла [2], Дж. Гідлі [7], Е. Зеєфрід [12], Х. Сона [13], Е. Масіні, В. Шульц тощо.

Мета дослідження - розкрити та коротко охарактеризувати ключові ідеї, концепції та події на шляху розвитку футурології, відзначити основних мислителів і науковців, яких із відстані теперішнього ми можемо назвати видатними футурологами свого часу. Для полегшення сприйняття історія розвитку футурології поділена на чотири основних етапи, останній з яких триває і в наш час. Щодо нього також важливо зрозуміти ті завдання футурології, що вважаються актуальними у сучасних умовах та які визначатимуть особливості іiі розвитку у найближчому майбутньому.

\section{Виклад основного матеріалу.}

1. Витоки. Враховуючи широке коло питань, якими займається футурологія, можна стверджувати, що іiі витоки сягають древніх часів. І справді, різноманітна діяльність (політика, економіка різних епох) невіддільно пов'язана із уявленнями про майбутнє і його передбаченням. Керівництво державою та суспільством здавна означало певний рівень планування та цілепокладання. У XIX ст. процеси індустріалізації на основі наукових відкриттів та їхнього впровадження у виробництво відкрили нові можливості для державних лідерів та впливових промисловців щодо втілення сміливих проектів суспільних перетворень і розвитку економіки. Індустріальна держава вимагала раціональних підходів до планування і управління, а швидкі зміни змушували задуматися про майбутнє.

Приймаючи за момент зародження нової дис- 
ципліни футурології закінчення Другої світової війни, відзначимо інтелектуальні та світоглядні системи, сфери прояву людського мислення, які послужили для неї основою та протягом тривалого часу і до сьогодні допомагають людям осмислювати проблеми майбутнього [13, с. 120-137].

1) Релігія вперше запропонувала порівняно складні концепції минулого і майбутнього, уявлення про призначення людини і їі цілі у житті як частини цілісних систем світогляду і світосприйняття. Прикладами є циклічні концепції дхармічних релігій - індуїзму, джайнізму, буддизму, сикхізму, які передбачають безкінечні перевтілення душі після смерті та циклічну історію людства чи ідеї про кінець світу та Страшний суд у авраамічних релігіях - юдаїзмі, християнстві та ісламі. Значення релігій полягає ще й у тому, що вони суттєво вплинули на філософію, мораль, утопії, художню творчість, які зі свого боку стали підгрунтям сучасної футурології.

2) Утопії - описані у літературі моделі ідеального суспільства часто вважаються прямим попередником футурології у справі проектування бажаних варіантів майбутнього. Починаючи із «Держави» Платона, «Нової Атлантиди» Френсіса Бекона та «Утопії» Томаса Мора і до теперішніх часів автори утопій на основі раціонального мислення та прийнятих ними цінностей намагаються запропонувати певний відмінний від теперішнього образ майбутнього, який, на їхню думку, заслуговує на те, щоби бути втіленим у реальності. Поряд із утопією іде антиутопія / дистопія як образ небажаного майбутнього - застереження людству про існуючі негативні явища та процеси, які можуть призвести до трагічного кінця.

3) Наукова фантастика - жанр художньої творчості, що часто змальовує образи майбутнього, містить елементи утопії чи антиутопії та базується на припущеннях про майбутні науково-технологічні винаходи, можливий хід історії, соціальний i культурний розвиток людства. Вже в другій половині XIX ст. засновники наукової фантастики Жуль Верн та Герберт Веллс у своїх творах наголошують на здатності науки зробити світ кращим та зображують хитромудрі способи застосування нових технологій. Проте непомітним для них не залишається і зворотна сторона. Зокрема, у романі «Париж у XX столітті», написаному у 1864 р., Жуль Верн змальовує похмуру антиутопію - світ, у якому немає місця для творчості і краси, натомість все поглинула техніка і раціональний розрахунок. Герберт Веллс у своїй «Машині часу» (1895р.) описує повне виродження людства у віддаленому майбутньому внаслідок невирішених проблем соціальної нерівності, а у «Острові доктора Моро» (1896 р.) викриває наслідки людського самолюбування, зображаючи жахливі експерименти люди- ни над тваринами заради наукової доцільності.

Загалом значення фантастики для футурології у тому, що вона сприяє усвідомленню і обговоренню важливих існуючих чи ймовірних майбутніх суспільних проблем, продукує нові образи майбутнього чи альтернативного минулого й теперішнього, розширюючи горизонти мислення, змушує широкі маси населення задуматись над проблемами і перспективами людства. Часто письменники-фантасти виробляють хорошу інтуїцію та здатні вдало передбачити майбутні події. Крім художньої літератури, вони вдаються до наукового прогнозування, а сформульовані ними ідеї надовго залишаються актуальними у значно ширшому контексті. Так, три закони робототехніки, вперше запропоновані Айзеком Азімовим у фантастичному оповіданні «Зачароване коло» (1942 р.), є предметом наукової дискусії і у XXI ст. у контексті проблеми загроз штучного інтелекту для людини.

Поряд із науковою фантастикою образи майбутнього з'являються і в інших формах масової культури. Зокрема, Всесвітня виставка 1939-1940 років у Нью-Йорку була присвячена темі «Світ завтрашнього дня» та містила спеціальну експозицію під назвою «Футурама» (яка у 1999 р. була запозичена при створенні однойменного популярного мультсеріалу про майбутнє), де були представлені модель та технологічні новації світу через 20 років.

4) Історицизм - термін, запроваджений Карлом Поппером у 1930-их рр., для позначення підходу, вираженого у низці соціально-філософських концепцій, які стверджують існування певних законів, паттернів, схем розвитку історії, ставлять за мету їхнє розкриття та передбачення майбутнього на цій основі. Прихильниками такого підходу були багато мислителів, починаючи $з$ античних філософів Геракліта, Платона, Аристотеля і до сучасних авторів. Видатними представниками історицизму $\epsilon$ Н. де Кондорсе, Вольтер, Г. Гегель, К. Маркс. Спроби віднайти циклічні чи лінеарні всезагальні закони суспільного розвитку є непоодинокими і в сучасних футурологічних працях. Однак, важливо пам'ятати, що багато з цих теорій сформульовані на основі погляду винятково у минуле, схильні помилково надавати теперішнім тенденціям статусу загальної закономірності та не здатні передбачити якісно відмінне від теперішнього майбутнє.

Крім цього, зародження футурології, безумовно, пов'язане 3 досягненнями соціальних наук у міжвоєнний період. У цей час низка соціологів, політологів, психологів, філософів займаються дослідженням тенденцій суспільного розвитку та чинників, які впливають на цей процес, намагаючись спрогнозувати майбутні події та визначити орієнтири для державного планування. Зокрема, відомий американський соціолог, один із фунда- 
торів соціології науки і техніки Вільям Огберн (William Ogburn) у 1920-1930-их рр. розробляє теорію соціальних змін та вивчає вплив технологій на суспільство. Відомою $є$ його теорія культурного відставання, що зумовлене неоднаковою швидкістю засвоєння різними суспільствами технологічних новацій, яку пізніше використав футуролог Е. Тоффлер у своїй праці «Шок майбутнього». У 1930-1933 рр. В. Огберн очолює створений президентом США Гербертом Гувером Комітет із дослідження соціальних тенденцій, серед основних досягнень якого підготовка детального звіту «Сучасні соціальні тенденції у Сполучених Штатах» (1933 р.). Пізніше він бере участь у розробці звіту Національного комітету ресурсів США під назвою «Технологічні тенденції і національна політика, включаючи соціальні наслідки нових відкриттів» (1937 р.) [2, с. 7].

2. Зародження футурології. У період із 1945 до середини 1960-их років відбулася низка ключових подій, які дозволяють стверджувати, що саме у цей час виникає окрема дисципліна - футурологія. Серед них - озвучення ідей про необхідність дисципліни, яка б займалася проблемами майбутнього, становлення перших футурологічних шкіл та організацій, створення впливових наукових концепцій, які не втратили актуальності і в теперішній час. Загалом цей період пов'язаний iз намаганнями раціоналізувати роздуми про майбутнє та пристосувати їх до практичних потреб.

У середині 1940-их років німецький науковець О. Флехтхайм (народжений в м. Миколаєві на території теперішньої України) пропонує назву «футурологія» (нім. futurologie), вкладаючи у це поняття широкий зміст: усі прогнози та проекції; усі процедури планування в економіці, освіті та інших сферах; визначення цілей, норм та цінностей, що стосуються майбутнього [6, с. 264-269]. У 1948 р. у США заснована незалежна дослідницька організація RAND Corporation - перший аналітичний центр світу, завданням якого є застосування наукових підходів для вирішення суспільних проблем, покращення політики та вдосконалення методів прийняття рішень. Діяльність цієї організації мала значний вплив на розвиток футурології та наукового прогнозування. У 1950 -их роках у іï межах був розроблений один із найвідоміших методів прогнозування за допомогою експертних оцінок - метод Дельфі. 3 RAND пов'язана кар'єра таких відомих футурологів, як Герман Кан та Френсіс Фукуяма, а також багатьох інших дослідників, які долучилися до становлення науки про майбутнє.

У 1950-1960-их роках важливим осередком розвитку футурології стає Франція. У 1957 р. філософ та міністр освіти Франції Гастон Берже (Gaston Berger) засновує Міжнародний центр майбутнього у Парижі та видає спеціалізований футурологічний журнал «Prospective». Сам термін «prospective», який використовує Г. Берже, означає науку про можливі варіанти майбутнього. Іншим впливовим французьким футурологом того часу є Бертран де Жувенель (Bertrand de Jouvenel), засновник організації «Association Internationale de Futuribles» та спеціалізованого журналу, автор праці «Мистецтво припущення» («L'art de la conjecture») [5]. Для позначення дисципліни про майбутнє Жувенель використовує створений ним за допомогою поєднання слів futurs та possibles термін futuribles, що означає саме ті варіанти майбутнього, які можна уявити і які, водночас, $є$ можливими, оскільки вони базуються на знаннях. За допомогою людських зусиль futuribles можуть бути втілені у життя, і за це людство та футурологи несуть особливу відповідальність. Жувенель одним iз перших розглядає майбутнє як сферу невизначеного, і тому для нього інтелектуальна робота, пов'язана із осмисленням майбутнього, $€$ швидше мистецтвом, а не наукою, що, проте, зовсім не применшує ролі наукових знань у цьому процесі [11, с. 593-594].

Етап зародження футурології невіддільно пов'язаний із реаліями Холодної війни, які змусили багатьох дослідників працювати над удосконаленням воєнної стратегії та розглядати перспективи знищення людської цивілізації внаслідок застосування ядерної зброї. Вже згадана корпорація RAND зародилася у межах військово-повітряних сил США як елемент системи забезпечення, передусім, цілей національної безпеки та оборони. Один із іï працівників, а згодом відомий футуролог Герман Кан (Herman Kahn) у 1950-их роках працює над проблемами наслідків ядерної війни та способами покращення шансів на виживання. У 1960 р. він публікує книгу «Про термоядерну війну», яка наражається на критику тих, хто звинувачує Кана у допущенні варіанту виживання США й після ядерної війни. 3 іншого боку, його роботи сприяють активізації суспільної дискусії i усвідомленню реальної загрози самознищення людства, а для футурології роблять важливий внесок у розвиток методу побудови сценаріїв. Згодом Г. Кан також стає широковідомим завдяки книзі у співавторстві із Е. Вінером «Рік 2000: основа для розмірковування про перспективи наступних 33 років» (1967р.) [9], у якій автори на основі власної індустріальної теорії формулюють прогнози на майбутнє.

У той самий час на європейському континенті австрійський журналіст і дослідник Робер Юнг (Robert Jungk) бере активну участь у кампаніях проти застосування ядерної зброї та публікує бестселер «Майбутнє вже почалося: могутність та безсилля Америки» (1952р.), у якому критикує США за надмірну віру в технологічний прогрес, 
який підпорядковує собі і природу, і людину [12, c. 5]. Крім того, основний внесок Р. Юнга у футурологію полягає в утвердженні активістського напряму, який передбачає залучення широкої громадськості до осмислення і обговорення проблем майбутнього. У 1970-их роках він разом із співавторами розробляє широковживаний на сьогодні метод футурологічних семінарів (futures workshops), який націлений на стимуляцію нових ідей та вироблення рішень актуальних соціальних проблем під час роботи у групі учасників. У 1964 p. Р. Юнг разом із визначним норвезьким соціологом та політологом Йоганом Галтунгом (Johan Galtung) ініціюють створення міжнародної неурядової організації «Mankind 2000», що покликана сприяти суспільному розвитку і підтриманню миру на Землі.

Крім воєнних і безпекових проблем, пріоритетними для досліджень у цей період стають питання розвитку індустріальної економіки та іiі впливу на суспільство, які також розглядаються в межах парадигми Холодної війни. Різні автори порівнюють конкуруючі системи - капіталістичну і соціалістичну, роблять висновки про їхнє зближення у майбутньому під дією сил індустріалізму (Р. Арон, Дж. Гелбрейт, В. Ростоу, Я. Тінберген), намагаються передбачити подальші перспективи індустріальної економіки та майбутнього постіндустріального суспільства. У межах політичної науки значну увагу проблемам майбутнього надає визначний американський політолог Гарольд Лассвелл (Harold Lasswell), для якого процес прийняття політичних рішень тісно пов'язаний із уявленнями про альтернативні варіанти майбутнього, знаннями про минуле, а також цілями та цінностями. У своїх роботах він обгрунтовує необхідність систематизації і розвитку знань про майбутні перспективи у глобальному масштабі, застерігає про небезпеки становлення авторитарної держави під впливом існуючих тенденцій та наголошує на важливості цінностей демократії і прав людини у нових умовах [2, с. 47-56].

Підсумовуючи, звернемо увагу на класифікацію німецької дослідниці Е. Зеєфрід, яка виділяє три основні напрямки футурологічних досліджень, що сформувалися на Заході у 1950-1960-их роках. Перший - емпіричний або позитивістський, пов'язаний з екстраполяцією тенденцій, прогнозами, сценаріями і представлений Г. Каном. Другий - нормативний або онтологічний, спрямований на пошук бажаних варіантів майбутнього у історичній і філософській перспективі, найпомітнішим представником якого був Б. де Жувенель. Третій - критичний або емансипаційний, розвинутий у роботах О. Флехтхайма, Р. Юнга, Й. Галтунга, сформувався під впливом ідеалістичного світогляду та зосереджений на здійсненні впливу на громадянське суспільство та соціальні рухи за допомогою публікацій, дискусій, публічних заходів [12, c. $4-5]$.

3. Виникнення основних концепцій та інституцій. На наступному етапі, який охоплює період із кінця 1960-их до початку 1990-их років, відбувається утвердження дисципліни futures studies у міжнародному масштабі, виникають основні організації та наукові журнали, з'являються перші навчальні програми. Теорії постіндустріального суспільства набувають домінантного статусу, а обговорення глобальних проблем, зокрема у сфері охорони довкілля і збереження ресурсів, стає загальним трендом.

У 1965 р. Американська академія мистецтв i наук створила Комісію щодо 2000 року з такими цілями: визначення проблем, 3 якими ймовірно зіштовхнуться наступні покоління, та стратегій їхнього вирішення; передбачення головних структурних змін у суспільстві та відповідних трансформацій цінностей; урахування ролі планування та передбачення; сприяння появі в інтелектуальній традиції більш прагматичних і менш утопічних та апокаліптичних поглядів на майбутнє [1, с. 24-29]. Головою Комісії став американський соціолог Деніел Белл (Daniel Bell), який на основі проведеної роботи опублікував у 1973 р. працю «Прихід постіндустріального суспільства: спроба соціального передбачення». У ній Д. Беллу вдалося запропонувати та обгрунтувати переконливу схему суспільно-історичного розвитку: «доіндустріальне - індустріальне - постіндустріальне суспільство», яка повинна була замінити застарілу марксистську ідею зміни суспільно-економічних формацій. Упродовж цього періоду з'явилося багато інших подібних теорій про суспільство, яке приходить на зміну індустріальному, під різними назвами (постіндустріальне, інформаційне, суперіндустріальне, знаннєве тощо). Однією з найбільш відомих і значимих серед них $є$ концепція американського соціолога i футуролога Елвіна Тоффлера (Alvin Toffler), викладена ним у книгах «Шок майбутнього» (1970р.) та «Третя хвиля» (1980р.). Іншим популярним футурологом, який працює у подібному руслі, є Джон Нейсбітт (John Naisbitt). Його перша книга, що стала світовим бестселером, «Мегатренди» була опублікована у 1982 р. Спільним для постіндустріальних теорій цього періоду є загалом оптимістичне ставлення до процесів суспільної трансформації, обгрунтування об'єктивного характеру змін та рекомендація адаптуватися до них якомога швидше.

Ще один центр генерації футурологічних ідей - Римський клуб (міжнародна неурядова організація, заснована італійським промисловцем і вченим Ауреліо Печчеі (Aurelio Peccei) у 1968 р.) розпочав свою роботу з набагато похмуріших і песимі- 
стичніших сценаріїв. Перша доповідь Римського клубу «Межі зростання», підготована колективом авторів на чолі з американським вченим Деннісом Медоузом (Dennis Meadows) у 1972 р., змалювала похмуру картину швидкого вичерпання природних ресурсів та занепаду людської цивілізації. Вона мала значний резонанс та сприяла широкому міжнародному обговоренню глобальних проблем людства, а також утвердженню концепції сталого розвитку (sustainable development). 3 того часу ця тематика стала однією з головних у межах футурологічних досліджень.

У ці ж роки виникають провідні футурологічні організації. У 1966 р. американський футуролог Едвард Корніш (Edward Cornish) заснував неурядову освітню та дослідницьку організацію під назвою World Future Society (WFS), яка $є$ професійною спільнотою футурологів та аналітичним центром, що об'єднує науковців, дослідників, підприємців і студентів. Метою організації $є$ налагодження контактів між людьми, які зацікавлені у реалізації бажаних варіантів майбутнього, сприяння обізнаності населення 3 проблемами сучасного світу, створення умов для вироблення рішень і заміни застарілих систем новими. 3 часу свого заснування WFS видає спеціалізований журнал «Futurist». У 1977 p. Е. Корніш разом з іншими членами організації опублікував книгу «Вивчення майбутнього: вступ до мистецтва і науки розуміння і формування завтрашнього світу», у якій здійснена систематизація тогочасних знань в галузі футурології - розкрито історію, принципи, методи досліджень, відзначено основні загрози для цивілізації та роль утопії у проектуванні кращого майбутнього, охарактеризовано концепції провідних футурологів [14].

Ідея про створення іншої впливової міжнародної організації - Світової федерації футурології (World Futures Studies Federation, WFSF) - зародилася на Першій світовій конференції з футурології, яку проводила в Осло у 1967 р. уже згадана організація «Mankind 2000». Ініціаторами створення WFSF були відомі футурологи, що представляли різні країни і дослідницькі центри, зокрема Й. Галтунг, Р. Юнг, Б. де Жувенель, І. Бестужев-Лада та інші. Сама організація була створена у 1973 р. в Парижі, а її першим президентом став Б. де Жувенель. Також у різний час її очолювали такі футурологи зі світовим ім'ям, як Й. Галтунг, Е. Масіні, Дж. Дейтор, Р. Слотер, Дж. Гідлі. Сьогодні Світова федерація футурології $є$ глобальною неурядовою організацією, що об'єднує членів із більш ніж 60 країн світу і має статус консультативного партнера ООН та ЮНЕСКО.

Із середини 1960-их років починають з'являтися перші навчальні дисципліни, присвячені футурології. Зокрема, у 1966 р. Е. Тоффлер уперше про- читав курс лекцій «Соціальні зміни і майбутнє» в Новій школі соціальних досліджень у Нью-Йорку, у 1967 р. Дж. Дейтор започаткував вивчення футурології у Вірджинському політехнічному університеті, а В. Белл запровадив вивчення дисципліни «Соціологія майбутнього» у Сльському університеті. Згодом кількість подібних курсів значно збільшилася і вже у 1973 році становила більше ніж 350 лише у США та Канаді [2, с. 62-63]. Також зявляються впливові наукові періодичні видання - «The Futurist» у 1967 p., «Futures» у 1968 p., «Futurics» у 1976 р. та інші.

4. Систематизація знань та нові виклики глобалізованого світу. Для сучасного етапу розвитку футурології, починаючи з 1990-их років, характерними $є$ систематизація футурологічних знань, принципів, засад діяльності, а також необхідність реагування на нові виклики, зумовлені глобалізацією, трансформацією світового порядку, деградацією довкілля та швидким розвитком технологій. Найбільш значимими на шляху розвитку теорії футурології у цей час можна вважати фундаментальну двотомну роботу В. Белла «Основи футурології» 1997 р. [2; 3], а також «Базу знань 3 футурології» за редакцією Р. Слотера, що видається починаючи із 1996 р. [10]. У плані методології важливими є роботи С. Інаятулли, у яких він розкриває засади запропонованого ним методу досліджень - причинного багатошарового аналізу (CLA), який втілюе основні переваги футурологічних підходів до вирішення суспільних проблем [8].

Усе більше держав створюють спеціальні установи або підрозділи з питань майбутнього у межах виконавчої влади або при парламентах. Уже в 70-80-тих роках подібні структури існували в Швеції, Нідерландах, Новій Зеландії, Австралії. У 1995 р. створено Службу сценарного планування в структурі офісу прем'єр-міністра Сінгапуру для виконання функцій розробки сценаріїв розвитку країни, втілення їх у державну політику та вдосконалення методології сценарного планування. Варто також відзначити створений у 1993 р. Комітет iз питань майбутнього при парламенті Фінляндії, який перетворився у постійно діючий орган та існує до теперішнього часу. Комітет складається 3 парламентарів та виконує роль аналітичного центру, який досліджує варіанти майбутнього та перспективи розвитку науки і технологій [4, с. 32-40]. Враховуючи досвід передових держав світу у 2015 p. в Україні була створена Тимчасова спеціальна комісія Верховної Ради 3 питань майбутнього, яка провела кілька важливих заходів на актуальні теми сучасної футурології, однак у 2016 р. припинила своє існування.

Разом із тим у 1990-ті роки набуває значної популярності ще одна форма осмислення майбут- 
нього - форсайт (foresight), який тісно пов'язаний iз futures studies. Звичним явищем стає корпоративний форсайт - великі компанії на зразок Siemens, BMW, Shell розробляють і публікують власні прогнози на майбутне, які стосуються переважно сфери їхніх інтересів - економіки, технологій, енергетики. Уряди провідних держав світу - Японії, США, членів ЄС реалізовують програми державного форсайту, а міжнародні урядові організації здійснюють свої дослідження глобальних перспектив. Однак, суттєвим недоліком такої діяльності $є$ переважно економічна спрямованість. Державні і бізнесові структури використовують форсайт-дослідження, орієнтуючись переважно на потреби розвитку ринку та покращення економічних показників (навіть у випадку врахування ними чинників соціального розвитку та охорони довкілля) [13, с. 26-30]. Зважаючи на це, у науковому середовищі футурологів набуває поширення критичний підхід, який наголошує на важливості цінностей, моральних орієнтирів, прав і свобод людини.

Ще однією важливою проблемою сучасності $\epsilon$ швидкий розвиток технологій та їхній вплив на суспільство. За останні десятиліття звичними для усіх стали сценарії знищення цивілізації за допомогою технологій, які вийшли з-під контролю людини, що їх продукує у великих кількостях індустрія масової культури. Відбувається популяризація трансгуманістичного світогляду, який зорієнтований на радикальне вдосконалення людського організму за допомогою нових технологій. У багатьох футурологія починає асоціюватися із прогнозами про технологічні новації, сингулярність, роботів та штучний інтелект, які яскраво описані у роботах трансгуманістів та технооптимістів.

\section{Висновки та перспективи.}

Зважаючи на свою уже досить тривалу історію розвитку, футурологія може похвалитися значними здобутками i напрацюваннями, які не варто забувати чи ігнорувати, а навпаки - необхідно розвивати і враховувати у процесі роздумів про майбутні перспективи людства та під час розробки і втілення різноманітних проектів вдосконалення навколишньої реальності. Станом на сьогодні ми можемо констатувати значний потенціал футурології, який полягає у тому, що саме вона здатна запропонувати комплексні та розвинені підходи для: 1) критичної оцінки дійсності, виявлення хибних шляхів і загрозливих практик, зокрема на основі інтеграції різних форм людського досвіду минулих i теперішніх поколінь; 2) передбачення майбутніх змін, виявлення тенденцій з метою використання можливостей та усвідомлення загроз; 3) розробки образів бажаного майбутнього, виходячи за вузькі рамки галузевого проектуван- ня, припускаючи відкритість майбутнього та утверджуючи важливість творчих підходів, а також 4) втілення цих образів у життя за допомогою практичної діяльності, освіти, залучення населення до суспільно важливих проектів в атмосфері свободи і вільного вибору для кожного. Важливо реалізовувати ці завдання у комплексі, оскільки розробка образу бажаного майбутнього не буде плідною без критичного погляду на теперішнє i минуле та врахування існуючої динаміки розвитку. 3 іншого боку - розмови про бажане майбутнє без намагань втілити його у життя також видаються малопродуктивними.

Основними викликами, 3 якими доводиться зіштовхуватися футурології на сучасному етапі та які не знаходять належного реагування у межах інших традиційніших дисциплін і підходів (за винятком філософії), можна вважати такі проблеми:

1) Неконтрольований розвиток технологій, які, будучи породженням людського розуму, здатні привести людство до загибелі чи перетворити його на стадо рабів. Ідея про те, що морально-духовний розвиток людини може значно відставати від технологічного і це становить істотну загрозу існуванню $є$ не новою для футурології. Однак, тепер ідеться вже не лише про небезпеки ядерної війни чи деградації довкілля, а й про агресивні інформаційні та інші технології, націлені на свідомість і внутрішній світ людини.

2) Дегуманізація є пов'язаною із технологізацією усіх сфер життя та домінуванням економічних інтересів. Як наслідок, отримуємо освіту, яка вже не «несе світло» чи «творить особистість», а прищеплює набір «саме тих» компетентностей, що необхідні для виживання за умов диктату технологічної та економічної систем. Іншим прикладом $є$ виродження науки, для якої винайдення нового, витонченішого способу маніпуляції людиною-споживачем чи людиною-громадянином вважається великим успіхом.

3) Глобалізація усе більше набирає швидкості та в поєднанні з вищевказаними загрозами веде до тотальної уніфікації на всіх рівнях, починаючи 3 особистісного і закінчуючи великими економічними та політичними системами. У таких умовах зростає актуальність побоювань про виродження капіталізму (про це, зокрема, йдеться в останній доповіді Римського клубу «Come on!»), світову монополізацію, концентрацію нелегітимної влади у руках глобальних акторів, ерозію демократичного порядку, зростання нерівності, утвердження нового мовного і культурного колоніалізму.

Ці та інші виклики ще більше актуалізують холістичний, а не вузькогалузевий підхід до осмислення майбутніх перспектив та винайдення варіантів бажаного майбутнього, який протягом своєї уже 70-річної історії утверджує футурологія. 


\section{REFERENCES}

1. Bell, D. (1966-1967). Report of the commission on the year 2000. Records of the Academy (American Academy of Arts and Sciences), 1966/1967, 24-29. Retrieved from: https://www.jstor.org/stable/3785461?seq=1\#page_scan_tab_contents 2. Bell, W. (2009). Foundations of futures studies: Human science for a new era. History, purposes, and knowledge. (Vol. 1). New Brunswick, NJ: Transaction Publishers.

3. Bell, W. (2009). Foundations of futures studies: Human science for a new era. Values, objectivity, and the good society. (Vol. 2). New Brunswick, NJ: Transaction Publishers.

4. Dator, J. (2011). Futures Studies. Leadership in Science and Technology, 1, 32-40. Retrieved from: http://www.futures. hawaii.edu/publications/futures-studies/DatorFuturesStudies.pdf

5. De Jouvenel, B. (1967). The art of conjecture. (N. Lary, Trans.). New York: Basic Books.

6. Flechtheim, O. (1967). Is futurology the answer to the challenge of the future. R. Jungk \& J. Galtung (Eds.). Mankind 2000 (pp. 264-269). London: Allen and Unwin.

7. Gidley, J. (2017). The Future: A very short introduction. Oxford: Oxford University Press.

8. Inayatullah, S. (1998). Causal layered analysis: Poststructuralism as method. Futures, 30 (8), 815-829.

9. Kahn, H., \& Wiener, A. J. (1967). The year 2000: A framework for speculation on the next thirty-three years. New York: Macmillan.

10. Slaughter, R. A., Inayatullah, S., \& Ramos, J. (Eds.). (2005). Knowledge base of futures studies. (CD-ROM). Indooroopilly, Qld.: Foresight International.

11. Masini, E. B. (1987). Tribute to Bertrand de Jouvenel. Futures, 19 (5), 593-594. 12. Seefried, E. (2013). Steering the future. The emergence of «Western» futures research and its production of expertise, 1950s to early 1970s. European Journal of Futures Research, 2 (1), 1-12.

13. Son, H. (2015). The history of Western futures studies: An exploration of the intellectual traditions and three-phase periodization. Futures, 66, 120-137.

14. Cornish, E. (1977). The study of the future: An introduction to the art and science of understanding and shaping tomorrow's world. Bethesda, MD: World Future Society.

\section{Сухорольський Петро Михайлович}

Кандидат юридичних наук, доцент

Національний університет «Львівськаполітехніка»

79013, м. Львів, вул. С. Бандери, 12

\section{Сухорольська Ірина Юріївна}

Кандидат полытичних наук, асистент

Національний університет «Львівська політехніка» 79013, м. Львів, вул. С. Бандери, 12

\section{Sukhorolskyi Petro}

$\mathrm{PhD}$ in International Law, Associate Professor

Lviv Polytechnic National University

12 Bandera street, Lviv, 79013, Ukraine

\author{
Sukhorolska Iryna \\ $\mathrm{PhD}$ in Political Sciences, Assistant Professor \\ Lviv Polytechnic National University \\ 12 Bandera street, Lviv, 79013, Ukraine
}

Email: sukhorolsky@1p.edu.ua

ORCID: 0000-0002-1689-3283

Email: sukhorolska@1p.edu.ua

ORCID: 0000-0002-5833-3217

Цитування: Сухорольський П. М., Сухорольська І. Ю. Основні етапи розвитку футурології та ії̈ завдання в умовах сучасного світу / П. М. Сухорольський, І. Ю. Сухорольська // Науково-теоретичний альманах «Грані». - 2018. - Т. 21. - № 3. - С. 116-123.

Citation: Sukhorolskyi, P.M., \& Sukhorolska, I.Yu. (2018). Osnovni etapy rozvytku futurolohii ta yii zavdannia v umovakh suchasnoho svitu [Futures studies: main stages of development and tasks in the modern world]. Scientific and theoretical almanac «Grani», 21(3), 116-123. 